\title{
Atatürk Döneminde Balkan Göçmenlerinin İskân Çalışmaları (1923-1938)
}

\author{
Yrd. Doç. Dr. Önder DUMAN*
}

\begin{abstract}
ÖZET
Atatürk döneminde Bulgaristan, Romanya ve Yugoslavya gibi Balkan ülkelerinden Türkiye'ye 410 bin dolayında Türk göçmen gelmiştir. Bu göçmenler nüfus yoğunluğu düşük olan bölgelere belli bir iskân programı dahilinde yerleştirilmişlerdir. Hükümetler gö̧̈menlerin başta barınma olmak üzere tüm sorunlarını çözmeye çalışmış, onları üretici konuma getirebilmek için gerekli tedbirleri almıştır.
\end{abstract}

Anahtar Kelimeler: Atatürk Dönemi, Balkanlar, Türkiye, Göçmen, İskân.

\section{The Settlement Efforts of Balkan Immigrants in Atatürk's Era}

\section{ABSTRACT}

Approximately 410.000 Turkish immigrants came to Turkey during Atatürk's era from the Balkan states. They were settled in various parts of Turkey where population density was low. The governments tried to solve issues of the immigrants such as accommodation, health etc. The government made attempts to make the immigrants to stand on their feet by providing jobs.

Key Words: Atatürk's era, The Balkans, Turkey, Immigrants, Settlement.

\section{GİRIŞ}

Tarihsel süreçte göç olgusuyla sıkça yüz yüze kalan Türkler, 19. yüzyılın sonlarından itibaren batı-doğu istikametinde, diğer bir ifadeyle Balkanlardan Anadolu'ya doğru bir göç hareketi içerisinde bulunmuşlardır.

* Giresun Üniversitesi Fen-Edebiyat Fakültesi Tarih Bölümü GİRESUN. onderduman@hotmail.com. 
Bu göç hareketi Osmanlıyı takip eden Cumhuriyet döneminde de ivme kaybetmeksizin devam etmiştir. Cumhuriyet dönemindeki bu göçler esas itibariyle iki önemli sebebe dayanmaktaydı. Bunlardan ilki genç Türkiye Cumhuriyeti'nin nüfus politikasıyla yakından ilgiliydi. 1912-1922 arasındaki on yıllık savaş döneminin sonrasında "eksik" ve sağlık sorunlarıyla iç içe bir nüfus devralan Türkiye, sosyal ve ekonomik alanlarda gelişme kaydedebilmek, dış kaynaklı tehdit ve emellere karşı ülkeyi korumak için artma esasına dayalı bir nüfus politikası takip etmek zorundaydı ${ }^{3}$. Bu dönemde nüfusun arttırılması hususunda dışarıdan göçmen getirilmesinin uygun bir çözüm yolu olacağı düşünülmekteydi. Nitekim bu düşünce daha Ocak 1923'te İzmit'te Gazi Mustafa Kemal Paşa tarafından şu cümlelerle dile getirilmişti: “... nüfusumuzu tezyid etmek lazımdır... Ĕger Rusya'dan da getirmek mümkün olursa oradan da getireceğiz. Fakat bence Garbi Trakya'dan kâmilen Türkleri nakletmek lazımdır..."

Göçlerin bir diğer sebebi ise Türklerin yaşadıkları ülkelerde kendini gösteren bir takım itici faktörlerdi. Bu faktörler esas itibariyle 1920'lerin ortalarından itibaren hemen hemen tüm Balkan ülkelerinde görülen siyasal, ekonomik ve toplumsal faşist hareketlerle yakından ilgiliydi. Nitekim bu dönemde özellikle Bulgaristan ve Romanya devletleri etnik yapıyı türdeş hale getirmek üzere azınlıkları "kaçırmăga" yönelik politikalar uygulamakta, faşist hareketlere göz yummaktaydılar. Can ve mal güvenliği tehlikeye giren, yaşam şartları zorlaşan Türkler için böyle bir durumda Türkiye'ye göç etmekten başka bir çare kalmıyordu. Nitekim Türkiye'nin de bu göçleri teşvik etmesiyle ${ }^{6}$ Balkan Türklüğü Anadolu'ya, Türk Bayrağının gölgesine sığınmaya çalışmıştır. Cevat Geray'ın tespitlerine göre 1923-1938 arasındaki dönemde Bulgaristan'dan 180.979, Yugoslavya'dan 111.273 ve Romanya'dan 113.760 göçmen Türkiye'ye gelmiştir? ${ }^{7}$ Toplam 410 bin dolayındaki bu göçmenlerin iskânı ise mevcut çalışmanın temasını oluşturmaktadır. Bu dönemin başında Türkiye ve Yunanistan arasında gerçekleşen mübadele uygulaması ile Anadolu'ya gelen 350 bin civarındaki

\footnotetext{
${ }^{1}$ Nedim İpek, “Atatürk Döneminde Türkiye'nin Nüfus Siyaseti”, Beşinci Uluslar arası Atatürk Kongresi (8-12 Aralık 2003), C: I, Ankara 2005, s. 174-175.

2 Yakut Irmak, "Atatürk Döneminde Nüfus Politikası", Atatürk Döneminde Türkiye Ekonomisi Semineri (8-9 Haziran 1981), 1981, s. 214.

${ }^{3}$ Kemal Arı, "Cumhuriyet Dönemi Nüfus Politikasını Belirleyen Temel Unsurlar", Atatürk Araștırma Merkezi Dergisi, C: VIII, S: 23, s. 416.

${ }^{4}$ Ar1 İnan, Mustafa Kemal Atatürk'ün 1923 Eskişehir-İzmit Konuşmaları, Türk Tarih Kurumu Yayını, Ankara 1982, s. 54.

${ }^{5}$ Bu politikalar için bkz. Yaşar Nabi Nayır, Balkanlar ve Türklük, 1936.; Bilâl Şimşir, Bulgaristan Türkleri, Bilgi Yaynevi, İstanbul 1986.; Önder Duman, “Atatürk Döneminde Romanya'dan Türk Göçleri (1923-1938)”, Bilig, S: 45 (Bahar 2008).

${ }^{6}$ Soner Çağaptay, "Kemalist Dönemde Göç ve İskân Politikları", Toplum ve Bilim, S: $92(2002)$, s. 224.

${ }^{7}$ Cevat Geray, Türkiye'den ve Türkiye'ye Göçler (1923-1961), Türk İktisadi Gelişmesi Araştırma Projesi, Ankara 1962, Ek Tablo 2.
} 
mübadilin iskân çalışmaları pek çok değerli araştırmacı tarafından incelendiğinden kapsam dışı bırakılmıştır .

\section{A. Göçmenlerin İskânı}

Atatürk döneminde Türkiye'ye gelen göçmenlerin iskânını 1923-1933 ve 1934-1938 şeklinde iki ayrı kesitte incelemek gerekmektedir. Nitekim iskân edilen göçmenlerin statüsü böyle bir ayrımı zorunlu kılmaktadır. ${ }^{9}$ İlk dönemde göçmenler çoğunlukla "serbest göçmen"10 olarak kabul edilmişken, ikinci dönemde gelenler "iskânll" "11 statüde işlem görmüşlerdir.

\section{1923-1933 Dönemi İskân Çalışmaları}

Yeni devletin temellerinin atıldığı ve bütçe imkânlarının oldukça sınırlı olduğu bu dönemde Türkiye Cumhuriyeti Mübadele, İmar ve İskân Vekâleti vasıtasıyla tüm olanaklarını Yunanistan'dan gelen mübadil Türklerin göç ve iskânı için seferber etmiş durumdaydı. Dolayısıyla bu şartlar altında Balkan ülkelerinden gelecek göçmenlerin iskân işlemlerinin devlet eliyle yürütülmesi pek de imkân dahilinde değildi ${ }^{12}$. Nitekim bu yüzden yukarıda da ifade edildiği üzere bu dönemde Balkanlardan gelecek Türk göçmenler için serbest göçmen olma, diğer bir ifadeyle iskân hakkı talep etmeme şartı koşulmuş ve bu şartı kabul edenlere ülkeye yerleşme izni verilmiştir ${ }^{13}$. Dolayısıyla bu durumda göçmenlerin ülkeye giriş yaparken yaşamlarını idame ettirecek bazı maddi olanakları da beraberlerinde getirmeleri gerekiyordu. Zaten hükümetin de bu hususu gelecek göçmenlere ön koşul

${ }^{8}$ Mübadillerin iskânı için şu değerli çalışmalara bakılabilir. Kemal Arı, Büyük Mübadele Türkiye'ye Zorunlu Göç (1923-1925), İstanbul 1995.; Nedim İpek, Mübadele ve Samsun, Ankara 2000; ; İbrahim Erdal, Mübadele (Uluslaşma Sürecinde Türkiye ve Yunanistan 1923-1925), İstanbul 2006.

${ }^{9}$ Gerek incelemiş olduğumuz Cumhuriyet Arşiv belgeleri ve gerekse Toprak ve İskân Genel Müdürlüğ̈u Arşivine dayalı çalışmalar yapan Cevat Geray’nn tespitleri 1923-1933 arasındaki dönemde gelen göçmenlerin büyük bir kısmının serbest statüde kabul edildiğini, 1934-1938 döneminde ise bu kez göçmenlerin çoğunlukla iskanlı statüde işlem gördüklerini işaret etmektedir. Zaten 1934 sonrası göçler Türkiye'nin Balkan ülkeleri ile yaptı̆̆ı ikili anlaşmaların bir sonucu olarak gerçekleştiği için, göçmenler anlaşmalar gereğince "iskânlı " statüde kabul edilmişlerdir. Bu konuda bkz. Başbakanlık Cumhuriyet Arşivi (BCA), 272.12/56.143.34.; BCA, 272.12/56.143.35.; Cumhuriyet, 28 Ağustos 1935, s. 2.; Son Posta, 28 Mayıs 1935.; Geray, Türkiye'den ve Türkiye'ye Göçler..., Ek Tablo 2.; Filiz Doğanay, "Türkiye'ye Göçmen Olarak Gelenlerin Yerleşimi”, II. Ulusal Sosyoloji Kongresi Toplum ve Göç, Devlet İstatistik Enstitüsü Yayını, Ankara 1997, s. 197.

${ }^{10}$ Hükümetten yardım talep etmemek şartıyla, istediği yere yerleşme hakkı verilen kimseler için kullanılan tabir.

${ }^{11}$ Hükümet yardımıyla iskân edilen ve gösterilen iskân mıntıkasında belli bir süre oturmak şartını kabul eden kimseler için kullanılan tabir.

${ }^{12}$ Bu konuda Dahiliye Vekili Şükrü Kaya 1935'te şu ifadeleri kullanmıştı: “...Devlet

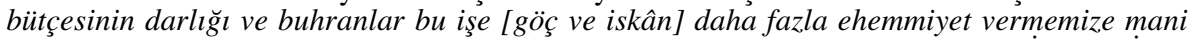
oldu..." Türkiye Büyük Millet Meclisi Zabit Ceridesi (TBMMZC), Devre(D): V, İçtima (I): 1 Cilt(C): 6, s. 78.

Başbakanlık Cumhuriyet Arşivi (BCA), 272.12/56.143.34.; 272.14/77.40.6.; $272.12 / 55.140 .12$. 
olarak sunduğu tespit edilmektedir. Örneğin Ekim 1925'te Bulgaristan'la yapılan bir sözleşme ile her ne kadar Bulgaristan'daki Türklerin hiç bir kısıtlamaya tabi tutulmaksızın Anadolu'ya serbestçe göç etmeleri kararlaştırılmışsa da, Türkiye Hükümeti almış olduğu bir kararla Yugoslavya'dan gelen göçmenler gibi Bulgaristan'dan gelenlerin de beraberinde belli miktarda bir para bulundurmasını istemiştir ${ }^{14}$. Bu dönemde Romanyalı Türk göçmenler de yine aynı koşulla Türkiye'ye gelebilmişlerdir ${ }^{15}$.

Uygulamaya göre göçmenlerden öncelikle iskân yardımı talep etmediklerine dair bir taahhüt senedi alınmakta ve bundan sonra kendilerine yerleşme hakkı verilmekteydi. Hükümet çoğunlukla iskân mıntıkasının neresi olacağına karışmamakta, göçmenlere bu noktada serbestiyet tanınmaktaydı. Göç ve iskân işlemleri bu şekilde yürütüle dursun, 1927 yılı sonlarından itibaren göçmenlerin yerleştikleri mıntıkalardaki mülkî idarecilerden gelen raporlar söz konusu sistemin pek de istenildiği biçimde işlemediğine dikkat çekiyordu. Nitekim raporlara göre göçmenlerin büyük bir çoğunluğu yeterli maddî imkâna sahip olmadığ 1 halde sırf ülkeye giriş yapabilmek için iskân yardımı almayacağına dair taahhüt senedi vermekte, ancak bir süre sonra bunlar doğal olarak muhtaç duruma düşmekteydiler. Raporlarda göçmenlerin ev, arazi ve tohumluk talebinde bulundukları dile getirilmekteydi ${ }^{16}$. Bu durum karşısında hükümet zorunlu bir biçimde 1926 İskân Kanunu'nun 5. ve 6. maddelerini esas alarak gerekli yardımı yapmak üzere çalışmalara başladı. Nitekim söz konusu maddelere göre 1 Temmuz 1926'dan sonra Türkiye'ye gelen muhacir ve mültecilerden "cidden muhtacı muavenet" durumda kalanlara, arazi verilmesi gerektiği ifade edilmişti. Hükümet bu esas uyarınca 1928 yılından itibaren Bulgaristan, Romanya ve Yugoslavya'dan gelen göçmenlerden muhtaç durumda kalanlara bütçe imkânları doğrultusunda iskân yardımı yapmaya çalışmıştır ${ }^{17}$. Bu dönemde gelen göçmenlerin nerelerde, ne miktarda yerleștiğine dair sağlıklı bir rakam vermek mümkün olmamakla birlikte, toplam 243 bin $^{18}$ göçmenin çoğunlukla Trakya ve Marmara havzasını kendilerine yerleşim alanı olarak seçtikleri tespit edilmektedir ${ }^{19}$.

\subsection{4-1938 Dönemi İskan Çalışmaları}

1930'ların başından itibaren gerek Balkan ülkelerinin türdeş etnik bir yapı kurmaya yönelik politikaları ve gerekse 1929 ekonomik bunalımının olumsuz etkileri özellikle Bulgaristan ve Romanya'daki Türk kitlenin göç

\footnotetext{
${ }^{14}$ BCA, 272.14/77.40.6.

${ }^{15} \mathrm{BCA}, 272.12 / 56.143 .95$

${ }^{16} \mathrm{BCA}, 272.12 / 58.154 .18$.

${ }^{17} \mathrm{BCA}, 030.10 / 81.530 .7$.

${ }^{18}$ Geray, Türkiye'den ve Türkiye'ye Göçler..., s. 11.

${ }^{19} \mathrm{BCA}, 40.01 / 1466.9 .2$.
} 
etme isteğini önemli ölçüde arttırmış ${ }^{20}$ ve bunun sonucunda Türkiye'ye yönelik iltica vakaları sıklaşmıştı. İlticaların önünün alınamayacağını gören hükümet, Balkanlardaki Türk kitlenin düzenli ve programlı bir şekilde Türkiye'ye taşınması hususunu düşünmeye başladı ${ }^{21}$. Nihayet 1934 yılı sonunda Bulgaristan'daki Türklerin planlı bir biçimde kitlesel olarak Türkiye'ye alınacağı yolunda bir karar alındı ${ }^{22}$. Bundan kısa bir süre sonra, 1935 yılı başında Romanya'daki Türk Elçisi Hamdullah Suphi Bey'den toplu göç için yaptığı çalışmaları hızlandırması istendi ${ }^{23}$. Dolayısıyla 1934 yılı sonu ve 1935 yılı başı itibariyle Bulgaristan ve Romanya'dan hükümetin denetim ve kontrolü altında kitlesel göçler başladı.

\section{a. Göcmenlerin Kabulï}

$\mathrm{Bu}$ dönemde gelen göçmenler iskânlı statüde işlem gördükleri için, göçün başlamasından üretici konuma gelene kadar geçen süreç tümüyle devlet sorumluluğu altındaydı. Dolayısıyla bu statünün gereği olarak nakliye ve tüm iskân hizmetleri devlet eliyle yapılmış, buna karşılık göçmenler de kendilerine gösterilen mıntıkalara yerleşmekle yükümlü kılınmışlardır.

Göçmenlerin kabul ve iskân işlemleri 21 Haziran 1934 tarihli İskân Kanunu'na göre yürütülmüştür. Nitekim bu kanuna göre Türkiye'ye yerleşmek maksadıyla gelen göçmenlerin "Türk ırkından" olması ve "Türk kültürüne bağll" bulunması gerekiyordu. Bu özelliklere sahip olmayanlar ile "anarşistler, casuslar, göçebe çingeneler ve memleket dışına çıkarılanlar" göçmen olarak kabul edilmeyecektii ${ }^{24}$. Dolayısıyla tüm bu koşulları sağlayan göçmenlere 1934 yılı sonundan itibaren Bulgaristan ve Romanya'daki Türk elçilik ve konsolosluklarından vize verilmeye başlanmışıtır.

Bulgaristan'dan gelen göçmenler için hem kara hem de deniz yolu seçeneği mevcuttu. Araba ve trenlerle gelen göçmenler Edirne Kırkağaç'ta karşılanmakta, misafirhanede kayıt ve tescil işlemleri ile sağlık muayeneleri yapıldıktan sonra iskân birimlerine sevk edilmekteydiler. Deniz yoluyla gelenler ise Varna'dan gemilere bindirilmekte ve iskân edilecekleri yere göre İstanbul Tuzla'ya ya da İzmir Urla'ya indirilmekteydiler. Romanya'dan gelen göçmenler için deniz yolunun dışında başka bir ulaşım seçeneği mevcut değildi. Köstence'den vapurlara bindirilen göçmenler Anadolukavağı'nda karaya çıkarılmaktaydılar ${ }^{25}$. Göçmenlerin indirildikleri

\footnotetext{
${ }^{20}$ Bilâl Şimşir, "Bulgaristan Türkleri ve Göç Sorunu”, Bulgaristan'da Türk Varlı̆̆ Bildiriler (7 Haziran 1985), Ankara 1992.; Duman, “Ảtatürk Döneminde..., s. 29-30.

${ }^{21}$ BCA, 030.10/241.629.15.

${ }^{22}$ Edirne Postasi, 13.1.1937, s.1.

${ }^{23}$ Duman, "Atatürk Döneminde..., s. 32.

${ }^{24}$ İskân Kanunu (Resmi Gazetenin 21 Haziran 1934 tarih ve 2733 numaralı nüshasından alınmıştır), İstanbul 1934, s. 4-5.

${ }_{25}$ Cumhuriyet, 14 İkinciteşrin 1935, s. 5.; Ulus, 16 Ağustos 1937, s. 2.; Ulus, 1 Eylül 1937, s. 2.
} 
bu yerlerin hepsinde birer "tahaffuzhane" bulunmaktaydı. Bu tahaffuzhanelerde Kızılay ekipleri tarafından göçmenlerin temizlikleri, sağlık muayeneleri ve aşıları yapılmaktaydı. Tahaffuzhanelerde ayrıca göçmenlerin ellerindeki paraları Türk Lirasına çevirebilmeleri için banka memurları da görevlendirilmişti ${ }^{26}$.

Tahaffuzhanelerdeki işlemlerin tamamlanmasından sonra göçmenler, misafirhanelere sevk edilmekteydiler. Kayıt ve tescil işlemleri yapılan göçmenlerin burada kaldıkları müddet içerisinde iaşeleri Kızılay tarafından kurulan aşevleri vasıtasıyla temin edilmekteydi ${ }^{27}$. Göçmenler burada tabiiyet beyannamesini imzalayarak bir "muhacir kâğıd" almakta ve bu muhacir kâğıdı vatandaşlığa kabule değin nüfus hüviyet cüzdanı olarak kullanılabilmekteydi $^{28}$. Göçmenlerin büyük bir kısmının tüm bu işlemleri İstanbul'da yürütüldüğü için, burada göçmenler için bazı ek tedbirler de alınmıştı. Örneğin İstanbul Valiliği tarafından Galata'da teşkil edilen bir büro Sıhhat ve İçtimai Muavenet Vekâleti memurlarına göçmen kayıt ve tescil işlemlerinde yardımcı oluyordu ${ }^{29}$. Diğger taraftan Emniyet Müdürlüğü de göçmenlerin can ve mal güvenliğini sağlamak üzere misafirhanelerin bulunduğu bölgelerde ek emniyet tedbirler almıştı ${ }^{30}$. Yine İstanbul'da misafirhanelerin yetersiz kalması durumunda göçmenleri barındırmak üzere vagonlar tahsis edilmişti ${ }^{31}$.

Misafirhanedeki işlemler tamamlandıktan sonra göçmenler kendileri için tespit edilen iskân mıntıkalarına sevk edilmekteydiler. Yola çıkarılan kafilelere Sıhhat ve İçtimai Muavenet Vekâleti ile Dahiliye Vekâleti tarafından görevlendirilen müfettişler eşlik etmekteydi. Sevkıyatlar mümkün olduğu kadar trenlerle yapılmakta, demiryolunun bulunmadığı yerlerde yük arabalarından istifade edilmekteydi ${ }^{32}$.

\section{b. Göçmenlerin İskân Birimlerine Yerleştirilmesi}

Gerek 1934 tarihli İskân Kanunu'nun hazırlanmasına yönelik taslak çalışmaları ve gerekse de Dahiliye Vekâleti Nüfus Umum Müdürlüğü'nün "nüfus kesafeti" ile ilgili araştırmaları bu dönemde göçmen yerleştirilecek iskân mıntıkaları hakkında önemli ipuçları vermektedir. Nitekim her iki çalışmada da toprak kısmı $762.736 \mathrm{~km}^{2}$ olan Türkiye'de $\mathrm{km}^{2}$ 'ye 20 nüfus düştüğü ifade edilmekte ve bu sayının oldukça yetersiz kaldığı dile

\footnotetext{
${ }^{26}$ Kizllay, 7. 12. 1937, s. 4.

${ }^{27}$ Son Posta, 27 İkincitesrin 1935, s. 1,9;; 28 İkincitesrin 1935, s. 1.; 14 Birincikanun 1935, s. 3. Kızılay tarafından Sirkeci, Tuzla, İzmit ve Urla' da açılan aşevlerinde 1936 yılı ortalarına kadar 23.558 göçmen iaşe edilmiştir. Ulus, 25. 12. 1937, s. 14.

${ }^{28}$ Son Posta, 6 Eylül 1935, s. 1,11.; Cumhuriyet, 19 Eylül 1935, s. 2.

${ }^{29}$ Haber, 6 Mayis 1935, s. 1, 2 .

${ }^{30}$ Cumhuriyet, 10 Temmuz 1934, s. 1, 4.

${ }^{31}$ Son Posta, 27 İkinciteşrin 1935, s. 1,9.

${ }^{32}$ Cumhuriyet, 14 İkinciteşrin 1935, s. 5.; Ulus, 29 Mayıs 1936, s. 1, 2.
} 
getirilmekteydi. Çalışmalara göre nüfus yoğunluğunun yüksek olduğu yerler İstanbul ve Doğu Karadeniz'di ve buralar muhacir iskân planı dışında bırakılmalıydı. $\mathrm{Km}^{2}$,ye İstanbul'da 5.672, Doğu Karadeniz'de ise 68 nüfus düşmekteydi. Buna karşılık Doğu Anadolu, Akdeniz, İç Anadolu ve Trakya mıntıkalarının nüfus yoğunluğu oldukça düşük seviyedeydi. Nitekim Doğu Anadolu'da nüfus yoğunluğu 12-15, Akdeniz'de 18, İç Anadolu'da 22 ve Trakya'da 27,5 'di. Dolayısıyla muhacir iskân planı için Trakya mıntıkasının tümü, Akdeniz'in ova ve yayla bölgeleri, İç Anadolu'nun sulama imkânı bulunan yerleri ile Doğu'da ziraat ve hayvancıllğa uygun bölgeler öncelikli

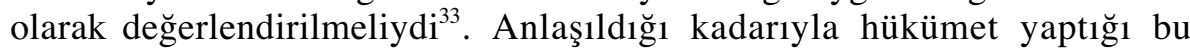
çalışmalarla iskân siyasetinin öncelikli hedefini atıl durumdaki toprakları üretime açmak, ekonomiye katkı sağlamak olarak belirlemişti.

$\mathrm{Bu}$ dönemde gazetelerde çıkan bazı yazılar da yine uygulanacak göçmen iskân planı hakkında önemli ipuçları vermektedir. Nitekim daha 5 Ocak 1933 tarihinde Cumhuriyet'te çıkan bir yazıdaki şu ifadeler oldukça dikkat çekicidir: “...Gelen muhacirler önce Trakya'ya yerleştirilmeli, Avrupa'da koca bir duvar dikilmelidir. Topră̆ l eken, yurdu güzelleştiren ve günü gelince onun için kanını döken adamdır, yurttaştır. Boş topraklar hiçbir işe yaramaz ve bir gün gelir başkalarının eline geçer. Edirne'de Kırklareli'nde bütün Trakya'da Bulgarların gözü vardır. Midye ile İnoz arasında bir çizginin üstünde kalan yerleri her gün bă̆ıra bağıra söylüyorlar. Ístanbul'da bile gözleri vardır. Bulgarların bu azgın açgözlülüğ̈̈ karşısında Türk'ün gözü Trakya'nın üstünden ayrılmamalıdır... Boğazlar, Ístanbul ve Trakya Türkiye'nin elinde olmasaydl, yeryüzünde bugünkü gibi saygı görmezdik, bugünkü gibi sözümüzü dinletemezdik. Bu yüksek değerli topraklarımızı sımsıkı tutmalıyız. Bu sımsıkı tutuşu ise Türk kollart ve göğ̈̈sleri yapabilir." ${ }^{34}$

Aynı konu ile ilgili yine Cumhuriyet'in 17 Temmuz 1935 tarihli sayısında Dahiliye Vekili Şükrü Kaya'ya hitaben şu yazıya yer verilmişti:

“ İ̧ Bakanımız Şükrü Kaya'ya,

...Trakya'yı ele geçirmek için Bulgarların firsat bulunca bize hücum edecekleri artık en küçük kuşkuya yer vermeyen bir gerçeklik olmuştur... yapılacak şey, Trakya'yı her bakımdan kuvvetlendirmektir... Hükümet Türkiye'ye gelecek yüz binlerce göçmeni Trakya'ya ve Doğu Anadolu'ya yerleştirme ğe karar vermiştir. Fakat görülü̈yor ki Bulgarların toprak doyurası aç gözlülü̈kleri karşısında Trakya'nın önemi büsbütün artmış ve bu sevgili Türk ili birden bire birinci plana geçmiştir. Onun için... Önce Trakya! Evet gelecek Türkleri önce Trakya'ya yerleştirelim... Önce

${ }^{33}$ BCA, 030.10/124.885.4. "Nüfus Kesafeti” s. 1-5.: BCA, 272.12/63.190.2. "Yerleşme Kanunu Niçin Yapıldı", s. 9-12.

${ }^{34}$ Cumhuriyet, 3 Birincikanun 1933, s. 1. 
Trakya" ${ }^{35}$ Her iki yazıdan da anlaşılacağı üzere göçmen iskân mıntıkaları hususundaki temel beklenti güvenlik odaklıydı. Trakya üzerinde iddia ve emelleri bulunan Bulgarlara karşı, bölgeye göçmen iskânının önemli bir güvenlik tedbiri olacağı düşünülmekteydi.

1934 yılı sonlarından itibaren kitlesel olarak Bulgaristan ve Romanya'dan gelmeye başlayan göçmenlerin iskân faaliyetleri bir bütün olarak değerlendirildiğinde gerek nüfus yoğunluğu meselesinin ve gerekse de güvenlik hususunun önemli ölçüde gözetildiği dikkati çekmektedir. Nitekim göçlerin başlamasıyla birlikte muhacirler öncelikle Trakya ve Doğu Anadolu'ya sevk edilmeye başlandı. Trakya'da Edirne, Kırklareli, Tekirdağ ve Çanakkale vilayetlerine bir yılı aşkın bir süre içerisinde 67 bin göçmen yerleştirildi $^{36}$. 1934 ve 1935 senelerinde Balkanlardan 81 bin dolayında göçmenin geldiği dikkate alınırsa ${ }^{37}$, göçmenlerin büyük bir çoğunluğunun, \% 82 'sinin Trakya'ya iskân edildiği ortaya çıkmaktadır. Geriye kalan 14 bin göçmen ise çoğunlukla Doğu Anadolu'ya yerleştirilmiştir. Doğuya gönderilen göçmenler Dördüncü Umumi Müfettişlik tarafından hazırlanan programa göre dört mıntıkaya iskân edilmişlerdir. Önem derecesine göre 1-4 şeklinde kademelendirilen bu iskân mıntıkalarından ilki Elazı $\breve{g}$, ikincisi Çapakçur ovası, üçüncüsü Elazı ̆̆-Muş demiryolunun ve şosesinin onar kilometrelik sağ ve sol tarafları ve dördüncüsü de Diyarbakır-Erzurum ve Palu-Erzincan yolu üzeriydi ${ }^{38}$. Bu planlama doğrultusunda yapılan iskân çalışmaları sonrasında göçmenlerin çoğunlukla Elazı ğ'a yerleştirildiği tespit edilmektedir. Nitekim Çemişkezek, Palu, Keban, Pertek ve Harput ilçeleri ile bunlara bağlı köylere iskân edilen göçmen miktarı 1935 yılı sonu itibariyle 5.600 'dü ${ }^{39}$. Yine aynı dönemde Iğdır'a 1.300, Muş'a 700 göçmen iskân edildi $^{40} .1935$ yılı sonuna kadar doğuya yönelik yoğun sayılabilecek bu iskân faaliyetleri sonraki yıllarda ivmesini kaybetti. Nitekim tespit edebildiğimiz kadarıyla 1936-1938 arasındaki dönemde Van'a 212 ve Diyarbakır'a 1.369 göçmen yerleştirilebildi ${ }^{41}$.

Doğuya yönelik tüm bu iskân faaliyetlerine karşıllk göçmenlerin bir kısmının bölgede kalmadığı, iskân hakkından vazgeçmek uğruna batıya döndüğü dikkati çekmektedir. 1935 yılında Muş'a sevk edilen 700 göçmenin daha bir yıl dolmadan iskân yerlerini terk ederek Çorum'a gelmeleri bu duruma dair önemli bir örnektir ${ }^{42}$. Göçmenlerin bu şekilde hareket etmeleri

${ }^{35}$ Cumhuriyet, 17 Temmuz 1935, s. 3.

${ }^{36} \mathrm{BCA}, 30.18 .1 .2 / 65.50 .14$.

${ }^{37} 1934$ ve 1935 senelerinde gelen göçmen miktarı 81.742'dir. BCA, 490.01/1466.9.2. Lef: 136

${ }^{38}$ Taș, Umumi Müfettișlikler, s. 158.

${ }^{39}$ BCA, 030.10/116.810.7.

${ }^{40}$ Son Posta, 27 Birinciteşrin 1936, s. 5.; Son Posta, 28 Birinciteşrin 1937, s. 3. 357,381

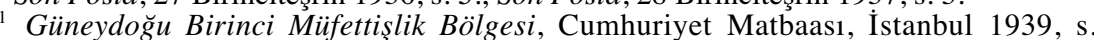

${ }^{42}$ Son Posta, 27 Birinciteşrin 1936, s. 5. 
tabii ki sebepsiz değildi. Nitekim bu hususta Birinci Umumi Müfettişlerinden Hilmi Ergenen şu tespitlerde bulunmaktayd1: "...Hariçten getirilecek ırkdaşlarımızın mıntıkanın lüzumlu yerlere yerleştirilmesine dayanan bu iş fedakârlık getirmektedir. Bölgeye ayrlan ödenekler azami tasarrufla idare edildiği halde, az sayıda getirilen muhacirlerin yerleştirilmesine dahi cevap vermeyecek miktardadır... Bölge halkının bir kısmı yapılan olumsuz propagandalar yüzünden muhacirlere sicak bakmamaktadır. Yurdumuza getirilen muhacirlerin geldikleri yere göre daha iyi şartlarda yaşaması gerekmektedir..."43 $\mathrm{Bu}$ ifadelerden de anlaşılacağ üzere göçmenlerin batıya gitmesinin başlıca sebebi iskâna ayrılan tahsisatın yetersizliği ve bölge halkının göçmenlere yönelik olumsuz bakışıydı. Bunlara ayrıca göçmenlerin bölge iklim ve coğrafyasına uyum sağlayamamaları, tevzi edilen toprağın verim kabiliyetinin düşük olması da eklenebilir" ${ }^{44}$ Doğudan batıya gelen göçmenler mevzuata göre "iskân hakkından" vazgeçmiş oldukları için, serbest göçmen statüsünde işlem görmüşler ve o zamana kadar kendileri için yapılan tüm iskân masrafları geri alınmıştır ${ }^{45}$.

Kitlesel göçün ilk yılı içerisinde gelen göçmenlerin çoğunlukla Trakya'ya iskânı ve dolayısıyla bu mıntıkanın "artık göçmen kabul edemeyecek" bir duruma gelmesi üzerine, 1936 yılından itibaren gelecek göçmenlerin Ankara, Yozgat, Kayseri, Niğde, Adana, Konya ve İzmit'e iskânı kararlaştırıldı ${ }^{46}$. 1936 yılı ortalarında alınan ikinci bir karar ile de göçmen iskân mıntıkalarının sayısı arttırılarak Tokat, Çorum, Bilecik, İçel,

${ }^{43}$ Hüseyin Koca, Yakın Tarihten Günümüze Hükümetlerin Doğu-Güneydoğu Anadolu Politikaları, Konya 1998, s. 416-417.

${ }^{44}$ Üçünü Müfettişlik Bölgesindeki valiler toplantısında tanzim edilen tutanağa bu konuyla ilgili su ifadeler konulmustu: “...Iğdır kazasına yerlestirilmis olan göçmenlerin vaziyetleri tetkik olunarak Kars valisinin vermiş olduğu izahata nazaran bu göçmenlerin ve yerli halkın sıhhi durumlarına en çok amil olan su ve bataklık vaziyeti olduğu anlaşılmıştır. (Zor) suyunun Iğdır'a getirilmesi, civar bataklıkların kurutulması, köylerde artezyen kuyularının açtırılması lüzumlu ve zaruri görülmüştür... Iğdır'a yerleştirilen göçmenleri esasen Iğdır'ı̧ iklimi ile istilas edemedikleri görülmüs ve bunların başka tarafa nakilleri hayatlarını kurtarmak için lüzumlu ad olunmuş ise de bu yolda Sıhhat ve İçtimai Muavenet Vekâletince bir kara ittihaz edilinceye kadar bu göçmenlerin muhtaç oldukları tohumluk ve yiyeceklerinin İskân Umum Müdürlüğünce celbi...” Ali Yıldırım, Cumhuriyet Dönemi İskân Politikaları, Anadolu Üniversitesi Sosyal Bilimler Enstitüsü (Yayımlanmamış Yüksek Lisans Tezi), Eskişehir 2004, s.104. Doğudan gelerek Samsun'a yerleşen göçmenler sert iklim koşullarından ve verimsiz topraktan şikâyet etmekteydiler. Öteden beri tütüncülükle uğraştıklarını söyleyen göçmenler, doğudaki olumsuz koşullar yüzünden tütün ekemediklerini, "sefil ve perişan" bir halde kaldıklarını dile getirmekteydiler. Samsun Bayındırlık ve İskân İl Müdürlüğ̈u Arşivi (SBİMA), Genel İskân Dosyası, Lef: 485-486.

${ }^{45}$ SBİMA, Genel İskân Dosyası, Lef: 486. Bu işlem 1934 İskân Kanunun 15. Maddesinin 5. Fikrasına göre yapılmıștır: "İskân yardımını birakarak serbest iskân isteyenlere, verilmis olan yapılar ve topraklar veya yapılan masraflar peşin olarak geri alınmak şartile Dahiliye Vekilliğince serbest iskâna izin verilebilir.” İskân Kanunu, s. 13.

${ }_{46}$ BCA, 30.18.1.2/65.50.14.; 030.10/123.839.5.; Son Posta, 17 İkincikanun 1936, s. 4.; Ulus, 9 İlkkanun 1936, s. 2.; Hikmet Öksüz, Batı Trakya Türkleri, Karam Yayıncılık, Çorum 2006, s. 46. 
Aydın Muğla, Isparta, Burdur, Manisa, Denizli, Antalya, Balıkesir, İzmir, Elaziz, Van, Muş, Diyarbekir, Ağrı, Kars ve Sivas’a da göçmen sevk edilmesi kararlaştırıld ${ }^{47}$. Nitekim bu karar gereğince 12 bin göçmenden 1.434'ü Tokat'a, 3.703'ü Kayseri'ye, 2.228'i Yozgat'a, 1.181'i Çorum'a2.452'si Konya'ya, 698'i Niğde'ye ve 203'ü de Bilecik'e iskân edildi $^{48}$. Geriye kalan yaklaşık 15 bin göçmen ise bunların dışında kalan vilayetlere yerleştirildi ${ }^{49}$.

1937 yılında gelen 26 bin $^{50}$ göçmenin önemli bir kısmı İzmir, Aydın, Manisa, Bursa ve Bilecik gibi Batı Anadolu vilayetlerine iskân edilirken, geriye kalan küçük bir kısım da Niğde, Sivas, Amasya ve Diyarbakır'a yönlendirildi' ${ }^{51} 1938$ yılında Türkiye'ye giriş yapan 20 bin $^{52}$ göçmen ise çoğunlukla Orta Anadolu'ya, Çorum, Yozgat ve Niğde vilayetlerine yerleştirildi ${ }^{53}$.

1934-1938 arasındaki dönemde Balkanlardan iskânlı göçmenlerin yanı sıra 14 bin civarında "serbest göçmen" de gelmiştir ${ }^{54}$. Bunlar iskân yardımı almamayı taahhüt ettikleri için, iskân programına bağlı kalmaksızın istedikleri mıntıkaya yerleşmişlerdir. Dolayısıyla serbest statüdeki göçmenlerin nerelere yerleştiği hakkında bir tespitte bulunmak oldukça zordur.

Kitlesel göçün ilk dönemlerinde başta mesken olmak üzere gerekli iskân hazırlıkları tam olarak yapılamadığı için, göçmenler evleri inşa edilene kadar yerli halkın yanına geçici olarak yerleştirildiler ${ }^{55}$. Bu geçici iskân döneminde göçmenlerin iaşe ihtiyaçları yerel idare tarafından karşılandı. Nitekim bu dönemde 12 yaşından küçüklere 60, 12 yaşından büyüklere de 120 'şer kg. yemeklik buğday tevzi edildi ${ }^{56}$. Yine ayrıca özellikle doğudaki göçmenlere yakacak yardımı yapıldı ${ }^{57}$.

Hükümet gelen göçmenlerin sağlık sorunlarıyla da yakından ilgilendi. Özellikle en yoğun göçmen nüfusu bünyesinde barındıran Trakya bölgesinde Kızılay vasıtasıyla "göçmen hastaneleri” açıldı. Çorlu, Keşan ve Gelibolu'da açılan toplam 80 yataklı üç hastanede 1936-1937 arasında 12 binin üzerinde göçmen muhtelif hastalıklara karşı tedavi edilirken, bu hastanelerde 58 bin

\footnotetext{
${ }^{47}$ BCA, 30.18.1.2/65.50.14.; Öksüz, Batı Trakya..., s. 47.

${ }^{48}$ Son Posta, 15 Temmuz 1936, s. 3.

${ }^{49}$ BCA, 490.01/1466.9.2.

${ }^{50} \mathrm{BCA}, 490.01 / 1466.92$

${ }^{51}$ Ulus, 6 Haziran 1937, s. 2.

${ }^{52}$ Geray, Türkiye'den ve Türkiye'ye..., Ek Tablo 2.

${ }^{53} \mathrm{BCA}, 030.10 / 81.531 .16$

${ }^{54}$ Geray, Türkiye'den ve Türkiye'ye..., Ek Tablo 2.

${ }^{55}$ BCA, 030.10/72.475.2.: Son Posta, 18 Birincikanun 1935, s. 4.

${ }_{57}^{56}$ Akşam, 22 Şubat 1935, s. 6.; Son Posta, 2 İkincikanun 1935, s. 2.

${ }^{57}$ BCA, 030.10/116.810.7.
} 
liranın üzerinde masraf yapıldı ${ }^{58}$. Sıhhat ve İçtimaiye Muavenet Vekâleti de yine bu bölgede salgın hastalıklara karşı bir doktor ile dört sıhhiye memurundan oluşan seyyar bir sağlık ekibi görevlendirdi ${ }^{59}$. Hükümet Trakya'nın yanı sıra doğuda, özellikle de Elaziz'de görevlendirdiği sağlık ekipleri vasıtasıyla salgın hastalıklara karşı tedbir alınmasını sağladı ${ }^{60}$.

Devlet bütçesinden yapılan tüm bu yardımlara halkın da katkısını temin etmek üzere bu dönemde tüm ülke çapında yardım kampanyaları açıldı. Hatta bu yardım kampanyalarına katılımı teşvik için gazetelerde sıkça ilanlar yayımlandı. Nitekim 19 Kasım 1934'te Trakyada Yeşilyurt gazetesinde çıkan bu tür bir ilanda şu ifadelere yer verilmişti: "Dış ellerden anayurda muhacirlerimiz gelmektedir. Bunlar Trakyamızın geniş topraklarını işleyecek; bu kollar yurdu zenginleştirecek, daha gönenletecektir. Bugün mini mini yavrularlyla, ihtiyar, sakat annelerle, hatta bir kısım yardım isteyen bir dermansızlıkla aramıza karışacak soydaşlarımıza, kardaşlarımıza karşı yardım elini uzatmak borcu karşısındayız... Durmak yok, çalışmak, yardım için elden gelen ne varsa yapmak var, bu, kardeşlik borcunun yapma ̆̆a bütün yurttaşlarımızı çağırıyoruz." ${ }^{61} \mathrm{Bu}$ duygusal içerikli çağrıların karşılıksız kalmadığı ve özellikle de Tekirdağ, Babaeski ve Çanakkale'de halkın göçmenlere nakdi ve ayni yardımlarda bulunduğu tespit edilmektedir ${ }^{62}$.

\section{c. Göçmenleri Üretici Konuma Getirmeye Yönelik Çalışmalar}

\section{c.a.Toprak Dă̆ıtımı}

İskân edilen göçmenlerin çoğu çiftçi olduğu için bunların üretici konuma getirilmesi hususunda öncelikle toprak dağıtımının yapılması gerekiyordu. Nitekim bu konu ile ilgili çalışmalar 1934 İskân Kanunu'na göre yapılmıştır. İskân Kanunu'na göre menşei ve cinsi ne olursa olsun bütün "millı" topraklardan, mera, baltalık ve fundalık gibi ortak mal hüviyetindeki ihtiyaç fazlası topraklardan, orman niteliğini kaybetmiş yerlerden ve hükümetçe istimlak edilecek çiftliklerden göçmenlere ziraat için yer verilmesi öngörülmüştü. Söz konusu arazilerin dağıtımında ise şu esaslara uyulacaktı: İki nüfuslu ailelere verim düzeyi yüksek topraklardan $30-45$, orta verimli topraklardan 45-60 ve düşük verimli topraklardan da 6090 dekar tarım arazisi verilecek, ikiden fazla her nüfus için de sırasıyla 10$15,15-20$ ve $20-30$ dekar arasında bir ilave yapılacaktı. Yine göçmenlere

${ }^{58}$ Trakya Dergisi, S: 7 (Şubat 1937), s. 12.; Kızılay, 6 Aralık 1937, s. 4.; Ulus, 25 Aralık 1937, s. 14

${ }^{59}$ Cumhuriyet, 2 Mayis 1935, s. 2.

${ }^{60}$ BCA, 030.10/116.810.7.; Turan, 14 Ağustos 1935, s. 1.

${ }^{61}$ Trakyada Yesilyurt, 19 Tessrini Sani 1934, s. 1.

${ }^{62}$ Akşam, 15 Kanunısani 1935, s. 3.; Akşam, 1 Şubat 1935, s. 6.; Akşam, 1 Mart 1935, s. 6.; Son Posta, 11 Şubat 1935, s. 4.; Çanakkale, 28 Mart 1935, s. 1. 
bahçe olarak 6-15 dekar arasında bir toprak verilecek, ikiden fazla her nüfus için de 2 dekarlık bir artırım mümkün olacaktı ${ }^{63}$.

Tüm bu esaslar dahilinde iskânlı statüdeki göçmenlere 1935 yılından itibaren toprak dağıtılmaya başlandı. İlk zamanlarda dağıtılan toprakların büyük bir kısmı mera, fundalık ve baltalık gibi ham, diğer bir ifadeyle ziraata yeni açılan araziden oluşuyordu. Dolayısıyla bu toprakların işlenmesi ve bir an önce mahsul verebilecek hale getirilebilmesi de ancak tarımda makineleşme ile mümkündü. Ülkenin mevcut bütçe imkânları bunu kısa sürede sağlamağa yetmediği için, göçmenler geleneksel yöntemlerle ziraat yapmak zorunda kaldılar. Bu durum doğal olarak göçmenlerin üretici konuma gelme süresini oldukça uzattı. Hükümet mevcut sorun karşısında ham arazi ile birlikte önceki senelerde işlenmiş topraklardan da belli bir miktarda göçmenlere verilmesinin uygun bir çözüm yolu olacağına karar verdi $^{64}$. Söz konusu kararın tatbiki için de hızlı bir biçimde istimlâk çalışmalarına başlandı. Nitekim bu çalışmalar özellikle Trakya'daki büyük çiftlikler üzerinde yoğunlaştırıldı. Tespit edebildiğimiz kadarıyla 1935 yılı başında sadece Tekirdağ'da 12 adet çiftlik devlet tarafından satın alınarak, göçmenlere tevzi edildi ${ }^{65}$. Yine Ayrıca Çorlu ve Silivri'de istimlâk edilen çiftliklere göçmenler yerleştirildi ${ }^{66}$. Trakya dışında Batı Anadolu'da, özellikle İzmir ve çevresinde satın alınan bazı çiftliklere de göçmen iskân edildiği tespit edilmektedir ${ }^{67}$.

\section{c.b. Tohumluk, Zirai Araç-Gereç, Hayvan ve Sermaye Yardımı}

Göçmenleri bir an önce üretici konuma getirmek isteyen hükümet, kitlesel göçün başladığı daha ilk günlerde tohumluk yardımı ile ilgili yasal düzenlemeleri hayata geçirdi. Nitekim 23 Aralık 1934 tarihli kanun ile Ziraat Bankası vasıtasıyla göçmenlere "zincirleme borçlanma" usulüyle iki yıl vadeli, bir milyon lira tutarında tohumluk buğdayın dağıtılması hususu karara bağlandı. Kanuna göre iki yılın sonunda borcunu ödeyemeyecek durumda olanların borçlarının iptali Bakanlar Kurulu kararı ile mümkün kılınmıştı ${ }^{68} .1936$ ve 1937 yıllarında kabul edilen iki kanunla Ziraat Bankası vasıtasıyla göçmenlere dağıtılacak tohumluk buğdayın bedeli önce $2.250 .000^{69}$ ve ardından da 3.750 .000 liraya çıkarıldd ${ }^{70}$.

${ }^{63}$ İskân Kanunu, s. 16, 33-34.

${ }^{64} \mathrm{BCA}, 030.10 / 72.475 .2$

${ }^{65}$ Haber, 25 Nisan 1935, s. 4.

${ }^{66} \mathrm{BCA}, 30.18 .1 .2 / 76.58 .5 .:$ Akşam, 1 Mart 1935, s. 5. 1937 yllına gelindiğinde Trakya'da istimlak için düşünülen çiftlik adedi 178'di. BCA, 30.18.1.2/54.31.1.; Son Posta, 30 Temmuz 1937, s. 5.

${ }^{67}$ Anadolu, 17.9. 1936, s. 3.

${ }^{68}$ Düstûr, Üçüncü Tertip, C: 16, Başvekâlet Matbaası, Ankara 1935, s. 467.

${ }^{69}$ TBMMZC, D: V, İ: 1, C: 7, s. 79.; Düstûr $r$ Üçüncü Tertip, C: 17, Başvekâlet Matbaası, Ankara 1936, s. 90

${ }^{70}$ Düstûr, Üçüncü Tertip, C: 18, Ankara 1956, s. 479-480. 
$\mathrm{Bu}$ yasal düzenlemelere bağlı olarak 1934 yılı sonundan itibaren göçmenlere tohumluk buğday dağıtımına başlandı. Nitekim 1934-1938 arasındaki dönemde Ziraat Bankası vasitasıyla 387.357 lira değerinde toplam 7.150.777 kilo tohumluk buğday tevzi edildi ${ }^{71}$. Yine aynı dönemde 128.059 kilo muhtelif ürün tohumu Sihhat ve İçtimai Muavenet Vekâletince çiftçi göçmenlere dağıtıldı. Dağıtılan tohumluğun ürünlere göre miktarı aşağıdaki tabloda gösterildiği şekildeydi ${ }^{72}$.

\begin{tabular}{|l|l|l|l|l|l|}
\hline Ürün & $\begin{array}{l}\text { Miktar } \\
\text { (kilo) }\end{array}$ & Ürün & Miktar (kilo) & Ürün & Miktar (kilo) \\
\hline Mısır & 8.158 & Arpa & 50.428 & Fĭ̆ & 1.290 \\
\hline Pamuk & 23.500 & Burçak & 6.348 & Mercimek & 2.076 \\
\hline Buğday & 7.065 & Nohut & 3.726 & Fasulye & 2.776 \\
\hline Çavdar & 19.455 & Soğan & 1.070 & Patates & 2.207 \\
\hline
\end{tabular}

Hükümet, çiftçi göçmenlerin toprağı işleyebilmesi için gerekli zirai alet ve edevatı da tedarik etmek üzere bazı çalışmalar yürüttü. Nitekim 1936 yılında sadece Trakya'daki göçmenler için 10 bin pulluk siparişi verildi ${ }^{73}$. Ertesi yıl teslim alınan bu pulluklara 5 bin tane daha ilave edilerek, 1937'de tüm Türkiye'deki göçmenlere toplam 15 bin pulluk dağıtıld ${ }^{74}$.

Zirai araç ve gerecin yanı sıra göçmenlere çift ve koşum hayvanları da verildi. Atlar Uzunyayla, Adana ve Kars'tan, öküzler ise Trakya, Çanakkale, Erzurum, Adana ve Sakarya'dan satın alınarak, göçmenlere dağıtıldı ${ }^{75} .1937$ yılı sonuna gelindiğinde dağıtılan çift hayvanı miktarı 15 bin civarındayd ${ }^{76}$.

Hükümet kırsal bölgeye yerleşen ve Türkiye'ye gelmeden önce arıcılıkla uğraşan göçmenlere de yardımlar yaptı. Bu kapsamda Trakya'ya yerleşen 100 arıcı göçmene 1936 yılında Ziraat Bankası vasıtasıyla 700 kovan tedarik edildi ${ }^{77}$.

$\mathrm{Bu}$ dönemde çiftçi göçmenlerin yanı sıra ticaret ve sanat erbabı göçmenlere de işletme kurabilmeleri için sermaye yardımı sağlandı. Tespit edebildiğimiz kadarıyla bu kapsamda 1936'da 11.241,90, 1937'de 7.454,50 lira para dağıtıldd ${ }^{78}$.

\footnotetext{
${ }^{71} \mathrm{BCA}, 490.01 / 1466.9 .2$

${ }^{72} \mathrm{BCA}, 490.01 / 1466.9 .2$

${ }^{73} \mathrm{BCA}, 30.18 .1 .2 / 63.27 .9$.

${ }^{74}$ Kizılay, 7.12.1937, s. 7.

${ }^{75}$ SBİMA, Hactkürtler Köyüne Ait Dosya, Lef. 11-12.; Son Posta, 10 Mart 1936, s. 5.

${ }^{76} \mathrm{BCA}, 490.01 / 1466.9 .2$.

${ }_{78}^{77}$ BCA, 030.10/116.810.14.; Haber, 22 Nisan 1936, s. 3.

${ }^{78}$ BCA, 490.01/1466.9.2.
} 


\section{d. Barınma Sorununun Çözümü}

Daha önce de ifade edildiği üzere kitlesel göçün başlamasıyla birlikte göçmenler iskân mıntıkalarında yerli halkın yanına misafir olarak yerleştirilmişti. Bu geçici bir çözümdü. Mevcut durumun gerek yerliler ve gerekse de göçmenler açısından sorunlara sebebiyet vermemesi için kalıcı çözüme, diğer bir ifadeyle yeni mesken inşasına ihtiyaç vardı. Bu yüzden 1935 yılı başından itibaren en yoğun göçmen iskân mıntıkası olan Trakya'da çalışmalara başlandı. Öncelikle inşaatlarda kullanılacak kerpiçlerin imali için yerli halk ile göçmenlerin imece usulüyle çalışmaları sağlandı ${ }^{79}$. Ardından tuğla ihtiyacını karşılamak üzere 25 kiremit ocağg kiraland ${ }^{80}$. İnşaat için gerekli kerestelerin bir kısmı Zingal Orman Şirketi vasıtasıyla temin edilirken, geriye kalan kısım Mersin, Bolu, Bozüyük, Bafra, Adapazarı ve İnegöl gibi yerlerden sağlandi ${ }^{81}$. Tüm bu hazırlıklar sonrasında ustalar ve marangozların denetiminde göçmenlerin bizzat çalışmaları suretiyle meskenlerin inşasına başlandı.

Trakya'daki göçmenlere yönelik bu inşaat çalışmaları beklenenden uzun sürdü. Tabii bu arada ülkedeki göçmen sayısı gün geçtikçe artıyordu. Trakya'daki mesken inşaatlarının öngörülen sürede tamamlanamaması üzerine göçmenlerin bizzat çalışması esasına dayanan yöntem terk edildi ve 1936 yllından itibaren göçmen evlerinin ihale yoluyla inşa ettirilmesi usulü benimsendi. Bunun için öncelikle yerel ve ulusal gazetelere ilanlar verildi. Söz konusu ilanlarda işçilik ve malzemenin müteahhide ait olacağı ve ihalenin "eksiltme" yöntemiyle yapılacağı duyuruldu ${ }^{82}$. Gazetelerden takip edebildiğimiz kadarıyla bu koşullarda çıkılan ihalelerin büyük bir kısmı "talipli zuhur etmediği" gerekçesiyle defalarca yenilendi, ama yine de "talipli" çıkmadı. Bu durumda ihale yönteminden vazgeçildi ve masrafları tümüyle devlete ait olmak üzere mesken inşaatların "emaneten" müteahhitlere bırakılması yoluna gidildi ${ }^{83}$.

Emanet usulüyle 1936 yılında başlatılan mesken yapım çalışmaları bir süre sonra kereste temininde yaşanan zorluklardan ötürü durma noktasına geldi. Bu durumda hükümet yurt dışından ve özellikle de Romanya'dan kereste temin edebilmek için 10 Ağustos 1937 'de bir kanun çıkarttı. Bu kanuna göre göçmenler tarafından Romanya'dan getirilecek $5 \mathrm{~m}^{3}$ 'e kadar olan keresteler tüm vergilerden muaf tutulacaktı ${ }^{84}$. Bu kanunun yürürlüğe girmesinin ardından ülkeye yeterli miktarda kerestenin girmeye başlaması ile

${ }^{79} \mathrm{BCA}, 030.10 / 72.475 .2$

${ }^{80}$ Akşam, 1 Mayıs 1935, s.1.

${ }^{81}$ BCA, 030.10/72.475.2:; 030.10/81.531.5.; Son Posta, 28 Nisan 1935, s. 4.

${ }^{82}$ Cumhuriyet, 8 Temmuz 1936, s. 11.; Son Posta, 26 Temmuz 1937, s. 11.

${ }^{83}$ Ulus, 6.9.1937, s. 6.; Turan, 9 Eylül 1936, s. 1.; Anadolu, 29 Temmuz 1937, s. 2.; Ulus, 1.8.1937, s. 10.; Ulus, 4.8.1937, s. 2.; Ulus, 10.8.1937, s. 10.; Son Posta, 31 Ağustos 1937, s. 3.

${ }^{84}$ Sicilli Kavanin, On Sekizinci Cilt 1937, Cihan Kitabevi 1938, s. 104. 
birlikte mesken inşaatları hızlandırıldı ve tamamlanan evler göçmenlere kademeli olarak teslim edilmeye başlandı. Mesken inşasına yönelik tüm bu çalışmalar neticesinde sadece 1934-1937 döneminde göçmenler için 18 bin dolayında ev inşa edildi ${ }^{85}$.

$\mathrm{Bu}$ dönemdeki göçmen yerleşimleri mevcut köylere ekleme yapmaktan ziyade müstakil köy kurmak esasına dayanıyordu. Kurulan köylerde genellikle geniş ve ağaçlı bir meydan bulunmakta, bu köy meydanında dükkânlar, doğum evi ve cami yer almaktaydı. Köyün hemen dışında ise okul, numune tarlaları ve spor alanları bulunmaktaydı ${ }^{86}$. Doğu Anadolu'nun dışında kalan yerlerdeki evlerin mimari tarzı hemen hemen aynıydı. Çoğunlukla iki veya üç oda, bir depo, bir ahır ve bir tuvaletten oluşan evler tek katlı ve çatılıydı ${ }^{87}$. Doğuda inşa edilen evler ise iki katlı olup, evlerin zemin katında bir hol ve bir oda, üst katta ise bir sofa ve yine bir oda yer almaktaydı. Ahır ve samanlıklar ise evin hemen bitişiğindeydi ${ }^{88}$.

Göçmenler kendilerine verilen evlerin bedelini 28 yılda ödemekle yükümlü tutulmuşlardı. Buna göre ilk sekiz yıl hiç ödeme yapılmayacak, borç bu dönemi takip eden 20 yıl içinde aylık taksitler halinde ödenecekti. $\mathrm{Bu}$ dönemde yapılan evlerin ortalama 500 liraya mal olduğu dikkate alınırsa $^{89}$, göçmenler yirmi yıl boyunca devlete aylık olarak yaklaşık 2 liralık bir ödemede bulundukları ortaya çıkmaktadır.

\section{SONUÇ}

Osmanlı'nın son yüzyılından itibaren Balkanlar ve Kafkasya'daki Türk ve Müslüman ahali için bir çekim merkezi olan Anadolu ve Trakya, Cumhuriyet döneminde de aynı yoğunlukta göç almıştır. Mübadele dışarıda bırakılacak olursa 1923-1938 arasındaki dönemde Bulgaristan, Romanya ve Yugoslavya'dan 400 binin üzerinde göçmen Türkiye'ye gelmiştir. İlk on yıllık dönemde serbest göçmen statüsünde kabul edilen muhacirler yardım alamamak koşulu ile istedikleri yere yerleşme imkânına sahip olmuşlardır. 1934 sonrasındaki dönemde gelen göçmenler ise iskânlı statüde işlem görmüşler ve belirli bir politika dahilinde iskân edilmişlerdir. Güvenlik ve atıl durumdaki toprakları üretime açmak şeklinde özetlenebilecek bu iskân politikası gereğince, Trakya ve Anadolu'nun nüfus yoğunluğu düşük bölgelerine göçmen yerleştirilmiştir. Böylelikle hem bazı güvenlik kaygıları giderilmiş, hem de ülkenin boş toprakları "şenlendirilmiştir". Mübadele deneyimin de etkisiyle göçmenler kısa sayılabilecek bir sürede iskân birimlerine yerleştirilmiş ve üretici konuma getirilmişlerdir.

\footnotetext{
${ }^{85}$ Cumhuriyet, 7 Mart 1938, s. 2.

${ }^{86}$ Kizılay, 7.12.1937, s. 4.

${ }^{87}$ Son Posta, 2 Birincikanun 1936, s. 1, 10.; Ulus, 7.5.1938, s. 6.

${ }^{88}$ Cumhuriyet, 21 Birinciteşrin 1935, s. 2.

${ }^{89}$ Son Posta, 13 İkincikanun 1936, s. 3.
} 


\section{KAYNAKLAR}

\section{A. Arşivler}

Başbakanlık Cumhuriyet Arşivi (BCA)

Samsun Bayındırlık ve İskân İl Müdürlüğü Arşivi (SBİMA)

\section{B. Resmi Yayınlar}

Düstûr (Üçüncü Tertip)

Sicilli Kavanin

Türkiye Büyük Millet Meclisi Zabıt Ceridesi (TBMMZC)

\section{C.Süreli Yayınlar}

Akşam

Anadolu

Cumhuriyet

Çanakkale

Edirne Postasl

Haber

Kuzılay

Son Posta

Trakya Dergisi

Trakyada Yeşilyurt

Turan

Ulus

\section{Kitap ve Makaleler}

Arı, Kemal, Büyük Mübadele Türkiye’ye Zorunlu Göç (1923-1925), İstanbul $1995 .$.

Arı, Kemal, "Cumhuriyet Dönemi Nüfus Politikasını Belirleyen Temel Unsurlar", Atatürk Araştırma Merkezi Dergisi, VIII/23: 409-420, 1992.

Babuş, Fikret, Osmanlı'dan Günümüze Göç ve İskân Siyaseti ve Uygulamalarl, Ozan Yayıncılık, İstanbul 2006. 
Çağaptay, Soner, "Kemalist Dönemde Göç ve İskân Politikaları”, Toplum ve Bilim, 93: 218-241, 2002.

Doğanay, Filiz, “Türkiye'ye Göçmen Olarak Gelenlerin Yerleşimi”, II. Ulusal Sosyoloji Kongresi Toplum ve Göç, Devlet İstatistik Enstitüsü Yayını, Ankara 1997.

Duman, Önder, “Atatürk Döneminde Romanya’dan Türk Göçleri (1923-1938)”, Bilig, S: 45 (Bahar 2008), s. 23-43.

Erdal, İbrahim, Mübadele (Uluslaşma Sürecinde Türkiye ve Yunanistan 1923-1925), İstanbul 2006.

Eski ve Yeni Toprak, İskân Hükümleri ve Uygulama Klavuzu, Hazırlayan: Naci Kökdemir, Ankara 1952.

Geray, Cevat, Türkiye'den ve Türkiye'ye Göçler ve Göçmenlerin İskânı (19231960), Ankara 1962.

Güneydoğu Birinci Müfettişlik Bölgesi, Cumhuriyet Matbaası, İstanbul 1939.

Irmak, Yakut, “Atatürk Döneminde Nüfus Politikası”, Atatürk Döneminde Türkiye Ekonomisi Semineri (8-9 Haziran), 1981.

İnan, Arı (1982), Mustafa Kemal Atatürk’ün 1923 Eskişehir-İzmit Konuşmaları, Türk Tarih Kurumu Yayınları: Ankara 1982.

İpek, Nedim, “Atatürk Döneminde Türkiye'nin Nüfus Siyaseti”, Beşinci Uluslar arası Atatürk Kongresi (8-12 Aralık 2003), C: I, Ankara, s. 174-175.

İpek, Nedim, Mübadele ve Samsun, Ankara 2000.

İskân Kanunu (Resmi Gazetenin 21 Haziran 1934 tarih ve 2733 numaralı nüshasından alınmıştır), İstanbul 1934.

Koca, Hüseyin, Yakın Tarihten Günümüze Hükümetlerin Doğu-Güneydoğu Anadolu Politikaları, Konya 1998.

KOLLU, Atilla, Türkiye Balkan İlişkileri 1919-1939, Hacettepe Üniversitesi Atatürk İlkeleri ve İnkılâp Tarihi Enstitüsü (Yayımlanmamış Doktora Tezi), Ankara 1996.

Öksüz, Hikmet, Batı Trakya Türkleri, Karam Yayıncılık, Çorum 2006.

Öksüz, Hikmet, Türkiye Cumhuriyeti Devleti'nin Atatürk Dönemindeki Balkan Politikası (1923-1938), İstanbul Üniversitesi Atatürk İlkeleri ve İnk1lâp Tarihi Enstitüsü (Yayımlanmamış Doktora Tezi), İstanbul 1996. 
Şimşir, Bilâl, "Bulgaristan Türkleri ve Göç Sorunu”, Bulgaristan'da Türk Varlı̆̆ı Bildiriler (7 Haziran 1985), Ankara 1992.

Taş, Serap, Umumi Müfettişlikler, Anadolu Üniversitesi Sosyal Bilimler Enstitüsü (Yayımlanmamış Yüksek Lisans Tezi), Eskişehir 1997.

Yıldırım, Ali, Cumhuriyet Dönemi İskân Politikaları, Anadolu Üniversitesi Sosyal Bilimler Enstitüsü (Yayımlanmamış Yüksek Lisans Tezi), Eskişehir 2004. 